International Journal of English Literature and Social Sciences
Vol-6, Issue-3; May-Jun, 2021
Journal Home Page Available: https://ijels.com/
Journal DOI: $10.22161 /$ ijels

Book Review

Peer-Reviewed Journal

\title{
Fundamentals of Academic Writing: Longman Academic Series, Linda Butler, Pearson, Longman. (2007). P236, ISBN: 9780131995574 \& ISBN: 013199557X
}

\author{
G. H. Abeyweera
}

Department of English Language Teaching (DELT), Uva Wellassa University of Sri Lanka

Received: 01 Feb 2021; Received in revised form: 21 Apr 2021; Accepted: 11 May 2021; Available online: 23 May 2021

(C)2021 The Author(s). Published by Infogain Publication. This is an open access article under the CC BY license

(https://creativecommons.org/licenses/by/4.0/).

\begin{abstract}
This paper is about review of a book entitled 'Fundamentals of Academic Writing' one of a series of books on the same topic which had been published intending for novice learners or more accurately novice writers of academic papers for the purpose of publication. The book 'Fundamentals in Academic Writing' authored by Linda Butler has been focused in particular for those who learn English as a Second or Foreign Language at any given level, be it students of Colleges, adult learners or the learners at secondary level. The text has been composed with a circumspect approach structuring the book in such a way extending support in developing essential skills in writing such as understanding writing as a process, and building (according to the writer Linda Butler) confidence and becoming independent writers. This book review therefore encourages learners to study, allude as a guide rather than a reference book for developing their academic writing skills at any level.
\end{abstract}

Keywords_Development Fundamentals, Review, Skills, writers.

The Book 'Fundamentals of Academic Writing' is a logically organized series of textbooks preparing learners for achieving their academic success. The text is primarily intended according to the author Linda Butler for beginners of second language learners in particular and as well as for adult learners having less exposure to academic writing (VII-Preface). Many scholars consider academic writing as a means to establishing an identity and seeking a place in the academic context. 'In academic writing, it is mandatory to produce logically structured ideas with wellthought out, verified points and to consider different opinions' (Gillet,Hammond \& Martala 2009). According to Monippally and Pawer (2010), the ideas of all categories of academic writing are centralized and people remain the background, the authors' feeling play no role whatsoever in the presentation of ideas or insights.

The title of the book suggests the fact that it guides the learners both young and adult to explore and learn the basics of academic writing due to the fact that organization of the book has a circumspect approach assisting learners to develop basic writing skills, to comprehend writing as a process while building a firm ground for the learners to be confident and independent academic writers in English. Because of this very reason, the book is more about academic writing than that of writing in academia.

If taken this as a whole series, the book offers a wealth of realistic models to inspire and guide the learners (Butler, L). The series also feature out precise exemplification of the syntactic structure, grammar and mechanics followed by substantial number of activities to be engaged by learners assimilating material and writing with accuracy. It focuses on the elements of good sentences within the context of lucid descriptive and narrative texts on learner centred topics. The text vividly combines a preamble to basic paragraph structure with an emphasis on self-writing, the type of writing most relevant and motivating learners at the initiative level. To do this, several interactive activities are designed to engage learners in the process of learning and complement the solidarity work the writers must do in academic writing. The text eventually provides directions for keeping a journal for journal entry topics so that learners continue to write for fluency building in 
addition to doing formal assignments. The text is organized in such a way that it begins with a picture to expose the learners and then to practice specific elements to be used in producing their own texts. The introductory section is followed by nine chapters of which each opener page of each chapter includes a picture and the title of the chapter for introducing the theme. Considering the preview of the chapters, it provides direction to learners to feel where they headed by providing two simple model paragraphs. The sentence structures and vocabulary are used in models easing the understanding and emulation. The attention of the learners is drawn by the posing of questions to the content and organization leading to the features of written language or the writers' language: different forms of the verbs, signaling words for transition, and vocabulary etc.

Although the first section deals by providing some exposure to understand what sentences and paragraphs look like and how their papers and written assignments should be for acceptance. The chapters in the second section deal with the elements of the standard paragraph structure, different patterns of organization with such standard paragraphs: order of organization, and then strategies for organizing learners' ideas.

The text basically has as stated before four components: the sentence structure, grammar, mechanics and vocabulary which are connected in many ways focusing on writing at the word and sentence level. In sentence structure, learners learn to identify the subjects and verbs and by combining how it makes sense through which they progress through four patterns of simple sentences followed by compound sentences with and, but and so and finally brief introduction to complex sentences with clauses of time.

Learners initially concentrate on parts of speech which come under grammar along with the structures to deal with paragraph writing. For example, the study about verb tenses required to write about day-to-day events.

Mechanics are basic elementary rules for punctuation, fullstops, titles, commas, colon, semi-colon etc. Then the vocabulary where learners enhance and improve their understanding of the parts of speech and broaden their vocabulary base, particularly in ways that assist learners with assigned writing.

In analyzing briefly about chapters, the chapter 1 deals about the process of writing. The learners learn the term 'process' and later they get an overview of writing process. The expansion activities proposed will enable learners to learn about organization in writing, sentence structure and mechanics, grammar and vocabulary and the writing process.
The chapter 2 deals with specific steps learners ought to take as they plan, compose and finalize their paragraphs. These are in other words fundamentals in writing required in producing paragraphs. Then chapter 3 onwards until chapter 9 , the text deals with guiding learners to deal with step by step through the process of writing the assigned paragraphs, initially with sufficient support later with increasing demand on their own creativity. The continuous practice of the activities proposed, learners get ample training to deal with assigned writing assignments. In addition, a concluding selection has been allocated in each chapter with two intended objectives of which one being to persuade journal writing and other being extra paragraphs writing tasks which provide further training for those who wish to write independently.

The process of writing or writing process which is explained in this text is noteworthy to observe for a while. As the text explains, it has four stages: prewrite, write, edit, and then writing the final draft in the process where learners learn to engage with interactive activities among each other, then writing, and then engaging in editing of what they wrote to organize the ideas gained through brainstorming, finalizing the final draft to be handed over to coacher once the learner is satisfied with what he/she has written on the give assignment.

Thus, it can be recommended that this textbook is useful and beneficial not only to whose who aspire to be academic writers but also to the general public as well. As Thomas and Reinertsen (2019). states 'academic writing needs to open itself up to broader audience and creative possibilities' this text 'Fundamentals of Academic Writing" can be recommended as a Handbook of Academic Writing rather than a guide for all levels of learners.

\section{Conclusion}

When all information so far discussed are sum-up, this textbook has proved to be a guide for all: young and adults aspiring to be academic writers in English. The book 'Fundamentals of Academic Writing' by Linda Butler is something like a game or any sport. According to the writer, as any two games are not alike for each has its own rules to be followed when in play. Thus, writing also has its own peculiar rules when writing matters. Just as every game is different, such is every bit of writing. This guide will undoubtedly assist those who wish to be aspiring writers to learn every piece of rules in writing depending on the nature of writing which will eventually pave the way for interested writers to paly the game in the context of academia 


\section{REFERENCES}

[1] Butler, L. (2007). Fundamentals of Academic Writing: Longman Series, Longman Publication.

[2] Gillett, A. \& Hammond, A. \& Martala, M. (2009). Successful academic writing. Essex: Pearson Longman

[3] Monippally, M.M. Pawer, B. S. (2010). Academic Writing- A Guide for Management Students and Researchers, New Delhi, Vivek Mehra for Response Books

[4] Thomas, L.M., Reinertsen, Anne, B. (2019). Academic Writing and Identity Constructions. Australian Cathelic University, Australia 